\title{
GIVING QUESTIONS AS SCAFFOLDING TO HELP STUDENT IN CONSTRUCTING PROOF
}

\author{
Nurul Laili*1, Tatag Yuli Eko Siswono ${ }^{2}$ \\ ${ }^{1,2}$ Universitas Negeri Surabaya \\ nurul.17030174057@mhs.unesa.ac.id*1 ${ }^{1}$, tatagsiswono@unesa.ac.id ${ }^{2}$ \\ *Corresponding Author
}

Received 30 August 2020; revised 03 October 2020; accepted 27 October 2020.

\begin{abstract}
ABSTRAK
Penelitian ini menjawab tantangan dalam membantu siswa yang mengalami kesulitan dalam menyusun pembuktian trigonometri. Penelitian kualitatif yang mendeskripsikan proses scaffolding dengan pertanyaan ini melibatkan 20 siswa kelas 2 SMA, yang kemudian dipilih 1 dari 11 siswa yang belum bisa menyelesaikan pembuktian secara lengkap. Hasil tes pembuktian dan rekaman wawancara adalah data yang dikumpulkan dan dianalisis untuk mengidentifikasi kesulitan yang dialami oleh siswa, jenis scaffolding yang dapat membantunya, serta perkembangan yang dihasilkan. Penelitian ini menunjukkan bahwa kesulitan yang dialami siswa dalam menyusun pembuktian diantaranya: kesulitan dalam menyusun strategi, stuck dalam proses, tidak dapat menentukan langkah selanjutnya, tidak dapat menemukan hubungan antara dua hal, melakukan langkah yang tidak tepat, serta menggunakan konsep yang tidak tepat. Scaffolding yang diberikan yaitu: menanyakan karakteristik dari bentuk yang akan dibuktikan, menanyakan konsep yang mungkin dapat digunakan, directive question, facilitative utterance, trans active prompt, dan scaffolding menggunakan analogi. Selanjutnya, perkembangan yang dihasilkan dari pemberian scaffolding tersebut adalah siswa dapat mengusulkan ide dan strategi baru, menemukan hubungan antara dua konsep atau dua hal, serta dapat menentukan dan menggunakan konsep yang tepat.
\end{abstract}

Kata kunci: pembuktian, pertanyaan, scaffolding, trigonometri.

\begin{abstract}
This research deals with the challenge of helping student who has difficulty in constructing trigonometry proof. This qualitative research that describing scaffolding process using questions involves 20 students in second grade of senior high school, then selects a student from the 11 students who cannot solve the proof completely. Student's work on proving test and interview recording are collected and analysed data to identify student's difficulty, type of scaffolding to help, and development produced. This research points out the difficulty student
\end{abstract}




\section{Nurul Laili, Tatag Yuli Eko Siswono}

faces are: difficulty in devising strategy, stuck in the process, unable to find the next step, and unable to find relation between two terms. Scaffoldings given are: asking the characteristic of what to be proven, asking a concept that may be used, directive question, facilitative utterance, trans active prompt and bridging analogy. Furthermore, developments produced from scaffolding given are: student can purpose new idea and strategy, can find relation between two things or two concepts, and student can determine and use appropriate concept.

Keywords: proof, question, scaffolding, trigonometry.

\section{INTRODUCTION}

Constructing proof is process of constructing argument deductively to show the truth of a proposition, communicate, and persuade others to accept the truth by using known mathematical elements, they are definition, axiom, and theorem (Doruk, 2019; Hanna, 2000). It is recognized as important part in mathematics education because it involves deductive and logical reasoning that increase students' comprehension in mathematics, critical thinking, and argumentation (Cyr, 2011; Hemmi \& Löfwall, 2010; Warli et al., 2020).

In line with the previous statements, Güler (2016) stated that ability to construct proof is very important because it improves problem solving skill and makes students have different points of view in solving mathematical problem. It develops reasoning skill, improves mathematical thinking skill, and contributes in improving mathematical communication skill, as well. So, it is not surprising if Güler (2016) stated that proof is the basis of mathematics, because it involves many important skills in mathematics. Beside that, it can show who understand mathematics deeply, not only execute some certain procedures, because it involves high-order thinking skills in building ideas and expressing them logically and systematically to construct the proof (Pantaleon et al., 2018). In addition, constructing proof is not only develops students' cognition, but also develops their character such as patience and persistence (Yazlik, 2019). The important role of proving in mathematics education is undeniable, however several research show that students still have some difficulties to construct it (Warli et al., 2020). Güler (2016) identified difficulties of proof that students face in four categories, they are difficulties in proof stem because of students' lack of prior knowledge, proof methods, executing certain procedure to construct proof, and biases against proof. 
According to several opinion that proving skill is very important in mathematics education, but in another side proving is still difficult for students, for that reason it is needed to find solution of this problem. These problem can be overcome by using scaffolding. Scaffolding is assistance provided by more competent peers or adults to fill in gaps between students' actual knowledge and potential knowledge by breaking complex problem into simpler one that slowly increase students' cognitive complexity to build complete concept, so they could then solve the problem they have (Belland \& Evidence, 2017; Schroeder, 2012; Slavin, 2006). The same is explained by Bikmaz et al. (2010) that the concept of scaffolding is used to define the role of more competent peers or adults in supporting students' learning development. Scaffolding can be in the form of actions that enable students to involve awareness of their thinking about the process and result of a problem. Blanton et al. (2009) divided instructional scaffolding in four types, they are:

Table 1. Type of Instructional Scaffolding

\begin{tabular}{|c|c|c|}
\hline No. & Type & Characteristic \\
\hline 1. & $\begin{array}{l}\text { Transactive } \\
\text { Prompts (TP) }\end{array}$ & $\begin{array}{l}\text { - Requests for explanations } \\
\text { - Request for justifications } \\
\text { - Request for clarifications } \\
\text { - Request for elaborations } \\
\text { - Request for strategies }\end{array}$ \\
\hline 2. & $\begin{array}{l}\text { Facilitative } \\
\text { Utterances (FU) }\end{array}$ & $\begin{array}{l}\text { - Re-voices or confirms student ideas } \\
\text { - Repeat or rephrase a student utterance }\end{array}$ \\
\hline 3. & $\begin{array}{l}\text { Didactive } \\
\text { Utterances } \\
\text { (DdU) }\end{array}$ & $\begin{array}{l}\text { - Teacher's utterances on the nature of } \\
\text { mathematical knowledge. }\end{array}$ \\
\hline 4. & $\begin{array}{l}\text { Directive } \\
\text { Utterances (DrU) }\end{array}$ & $\begin{array}{l}\text { - Teacher tells directly rather than elicit } \\
\text { information indirectly. }\end{array}$ \\
\hline
\end{tabular}

A teacher has a significant role in scaffolding process. The teacher can give scaffolding with guiding a discourse by asking purposeful questions to students -as one of scaffolding- and encourage them to share their ideas and 
strategies to others (Anghileri, 2006; Pfister et al., 2015). Baxter \& Williams (2010) differ scaffolding in two categories, they are social scaffolding and analytic scaffolding. Social scaffolding supports students to discuss and make interaction. It helps them to lean each other and work together rather than helps them to understand material directly, to complete mathematical task. While, analytic scaffolding supports students to understand material directly by giving them models, metaphors, representations, explanations, or justifications that can build mathematical understanding. Part of analytical scaffolding is provided by giving questions to make students focus and point out critical aspects of the mathematical concept being used (Baxter \& Williams, 2010).

Questioning is an important part in learning process that enables students to develop their thinking and effective learning. It is a vital component to help them reach educational objectives and facilitate their cognitive growth (Shahrill, 2013). Skillful questioning can provide students connecting some mathematical concept in solving proof problem which might never come to their minds.

Based on the problem stated in the previous paragraph, we can see that students need scaffolding in constructing proof. So, the author has an initiative to provide a solution that is having a research about "giving questions as scaffolding to help students in constructing proof'. This research aims to describe scaffolding process using questions for helping students in constructing proof.

\section{RESEARCH METHOD}

This qualitative research involves 20 students of 2 nd grade of Islamic Senior High School Miftahul Qulubin Pamekasan that given proving test. 4 students can complete it, 11 students can solve only parts of it, and 5 students left the answer sheet blank. A student was selected from 11 students who can solve only parts of proving test to be given scaffolding, because scaffolding is only needed by student who cannot solve the proving completely. The proving test given consists one problem, that is proving cosine rule as follows:

Given any triangle $\triangle P Q R$.

$p, q$, and $r$ are sides.

$\angle P$ is the angle opposite side $p$.

$\angle Q$ is the angle opposite side $q$.

$\angle R$ is the angle opposite side $r$. 
Prove that $q^{2}=p^{2}+r^{2}-2$.p.r.cos $\angle Q$ (this equation is known as cosine rule)

The data were collected trough proving test and interview. The subject is interviewed related to her process in constructing proof and she was given scaffolding in part where she had difficulty. The type of scaffolding given is adapted from Blanton et al. (2009), but all of scaffolding in this research is in question form. So, directive utterance type is changed into directive question (DrU), and Didactive Utterance (DdU) type may not be given in the scaffolding. Another type of scaffolding might appear excluded Blanton's type of scaffolding, and it is identified based on student's need in scaffolding section. Furthermore, the data based on the test and interview are analyzed qualitatively, carried out by identifying difficulties that the subject face in constructing proof, determining the type of scaffolding given, and identifying the implication of scaffolding toward development of student's ZPD by analyzing student's utterance.

Blanton et al. (2009) propose five student's utterances that show development within his/her ZPD:

1) Proposing new idea. It refers to students' new relevant information -it may be correct or not- that potentially useful in constructing the proof.

2) Proposing new plan or strategy. It refers to students' new plan or strategy that potentially useful in constructing a proof or some aspect of the proof. It is differed from proposing new idea because new idea might not entail a plan or strategy.

3) Contribution to development of an idea. It refers to students' utterance when they add idea to existing idea that proposed by other students in the class to solve a proof completely.

4) Transactive questions. It refers to students' question when they request for clarification, elaboration, critique, justification, or explanation of their peers' utterances.

5) Transactive responses. It refers to students' response, either direct or indirect response, to clarify, elaborate, critique, justify or explain one's thinking. 
These five types of utterances that show students' development within their ZPD can be found in a class. However, utterance that might show in this research is only first type and second type, because scaffolding in this research is given individually. So, there is no communication among students appears as in third, fourth, and fifth types.

\section{RESEARCH RESULTS AND DISCUSSIONS}

\section{Student's capability in proving before scaffolding}

The subject of this research (S1) begins the proving by understanding the problem. She determines what is known and what to be proven and she draw the illustration of the given problem. S1 thinks that to prove the theorem, she should use mathematical elements (definition, axiom, or theorem) and brings them to cosine rule form, but she does not know which mathematical elements she should choose. So, S1 manipulates what to be proven using trigonometric properties in right triangle and trying to find equality. In this case, she uses it in scalene triangle, hence, she cannot find equality. Actually, she knows that the process she carrying out is incorrect, but she does not want her work left blank. Proving process provided by $\mathrm{S} 1$ in Figure 1.

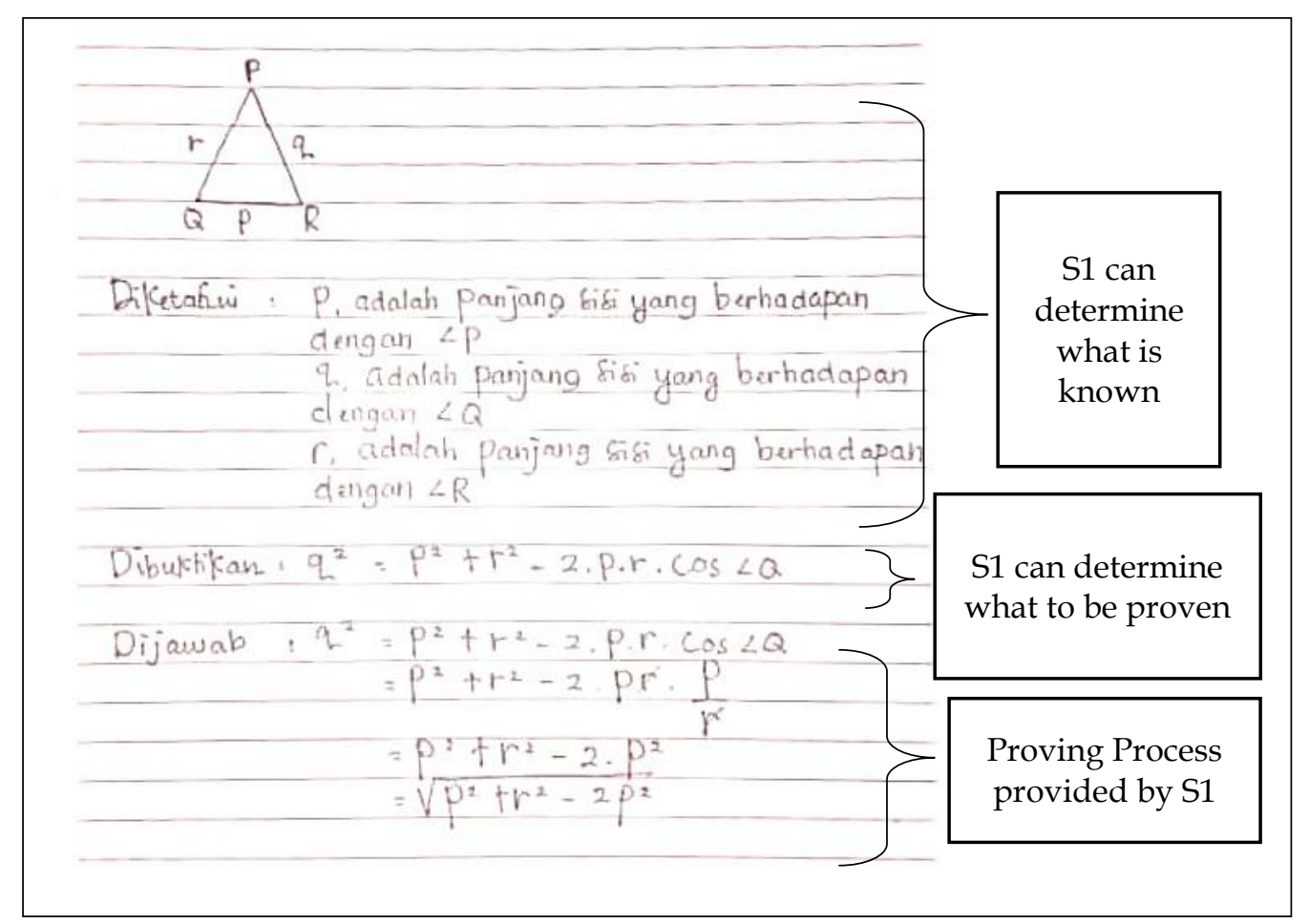

Figure 1. Proving Process Provided by S1 before Scaffolded 


\section{Scaffolding Process}

The first thing to do to help S1 in constructing proof is identifying the difficulties she has. Researcher identifies S1's first difficulty is unable to devise strategy in beginning the proof as the implication of student's lack of prior knowledge -rarely learn about proving in her school (Güler, 2016). To deal with this, researcher begins scaffolding by asking what is unique in the equation of cosine rule and what concept that might be used in proving cosine rule. This question supports $\mathrm{S} 1$ to find previous mathematical concept related to this problem. It is important step in constructing proof because it relates to Mathematical Connection Skill (Warli et al., 2020). The question aims to give her clue that the concept will use is Pythagorean Theorem, because lack strategic knowledge of how to choose facts and theorem to be applied is recognized as main cause of student's failure in constructing a proof (Weber, 2001). S1 answers something unique in the equation is containing square, like Pythagorean Theorem. Then she devises a strategy, that is constructing altitude to $\overline{Q R}$ trough $P$, namely $\overline{Q R}$. This finding a new strategy is evidence for development within S1's ZPD (Blanton et al., 2009).

Furthermore, $\mathrm{S} 1$ carries out the strategy, she gets $P R^{2}+P Q^{2}=$ $\left(P X^{2}+X R^{2}\right)+\left(P X^{2}+X Q^{2}\right)$, and gets stuck in this step. She feels that there is something wrong with her process, and researcher gives these following questions:
Researcher : Is PX one of term in cosine rule? .... How to make it gone? (TP-Request for Strategies)
S1 : Oh ya, there is no PX. So it should be eliminated (Proposal new idea).

Then she makes two equations, that is Pythagorean formula in $\triangle P X R$ and $\triangle P X Q$, and eliminates $P X$ and gets $q^{2}-r^{2}=X R^{2}-X Q^{2}$. But, she has difficulty in finding related concept. She does not know what to do next because she cannot find another concept that can be used to solve this proving (Warli et al., 2020). 
Researcher : What is relation between XRand XQ? (DrQ)

"Unable to go to the next step" is differed from "get stuck". "Unable to go to the next step" is difficulty when the student executes the right process but she does not know what to do next, while "get stuck" is difficulty when student does not know what to do next because of there is something wrong in the previous step. To help S1 in "unable to go to the next step", she is asked to find relation between XQ and XR, as directive question, but it does not work. She needs more specific clue to find it.

$$
\begin{array}{ll}
\text { Researcher } & : X R+X Q=?(\operatorname{Dr} Q) \\
\text { S1 } & : \text { Ohhh } X R+X Q=p . \quad \text { So, } \quad X R=p-X Q(\text { Find the } \\
& \text { relation between two things })
\end{array}
$$

She find that $X Q+X R=p$, but she does inappropriate step, by substituting $X Q$ by $p-X R$ and $X R$ by $p-X Q$, hence $p^{2}$ eliminated. It is not suitable with the equation in cosine rule, so she is asked for confirmation and requested for elaboration to make her focus on the goal she wants to achieve (Baxter \& Williams, 2010), that is cosine rule.

$\begin{array}{ll}\text { Researcher } & : \text { Hang on second. Did you substitute XR with } p-X Q, \\ & \text { and } X Q \text { with } p-X R ? \text { (FU-Confirmation) } \\ \text { S1 } & : \text { Yes } \\ \text { Researcher } & : \text { Why did you do that? (TP-Request for elaboration) } \\ \text { S1 } & : \text { (...) to eliminate } p \\ \text { (...) } & \\ \text { Researcher } & : \text { Please pay attention to the equation that will be proven. } \\ & \text { Is there } p \text { term there? (...) If yes, then why did you } \\ & \text { eliminate it? (TP-Request for elaboration) } \\ \text { S1 } & \text { Oh }\end{array}$

Then she realizes that she only need to substitute one of them, in this case she substitutes $X R=p-X Q$, to eliminate $X Q^{2}$ (propose new strategy). Hence she gets $q^{2}-r^{2}=(p-X Q)^{2}-X Q^{2}$. She thinks that $(a+b)^{2}=a^{2}+b^{2}$ as she did in the previous step. Then, researcher asks the result of $(5+2)^{2}$-as base problem- and asks S1 to make an explicit comparison with $(a+b)^{2}=a^{2}+b^{2}$-as target problem. This question is called as scaffolding with bridging analogy (Podolefsky, 2008). This question makes her remember about binomial expansion 
and applies it (Using appropriate concept), hence she gets $q^{2}-r^{2}=p^{2}-$ $2 p . X Q$. Furthermore, she uses trigonometric properties to find relation between $X Q$ and $\cos \angle Q$, and gets $q^{2}=p^{2}+r^{2}-2 p r \cos \angle Q$. Finally with the various types of scaffolding S1 solve the proof completely.

Scaffolding process toward S1 can be illustrated in Figure 2.

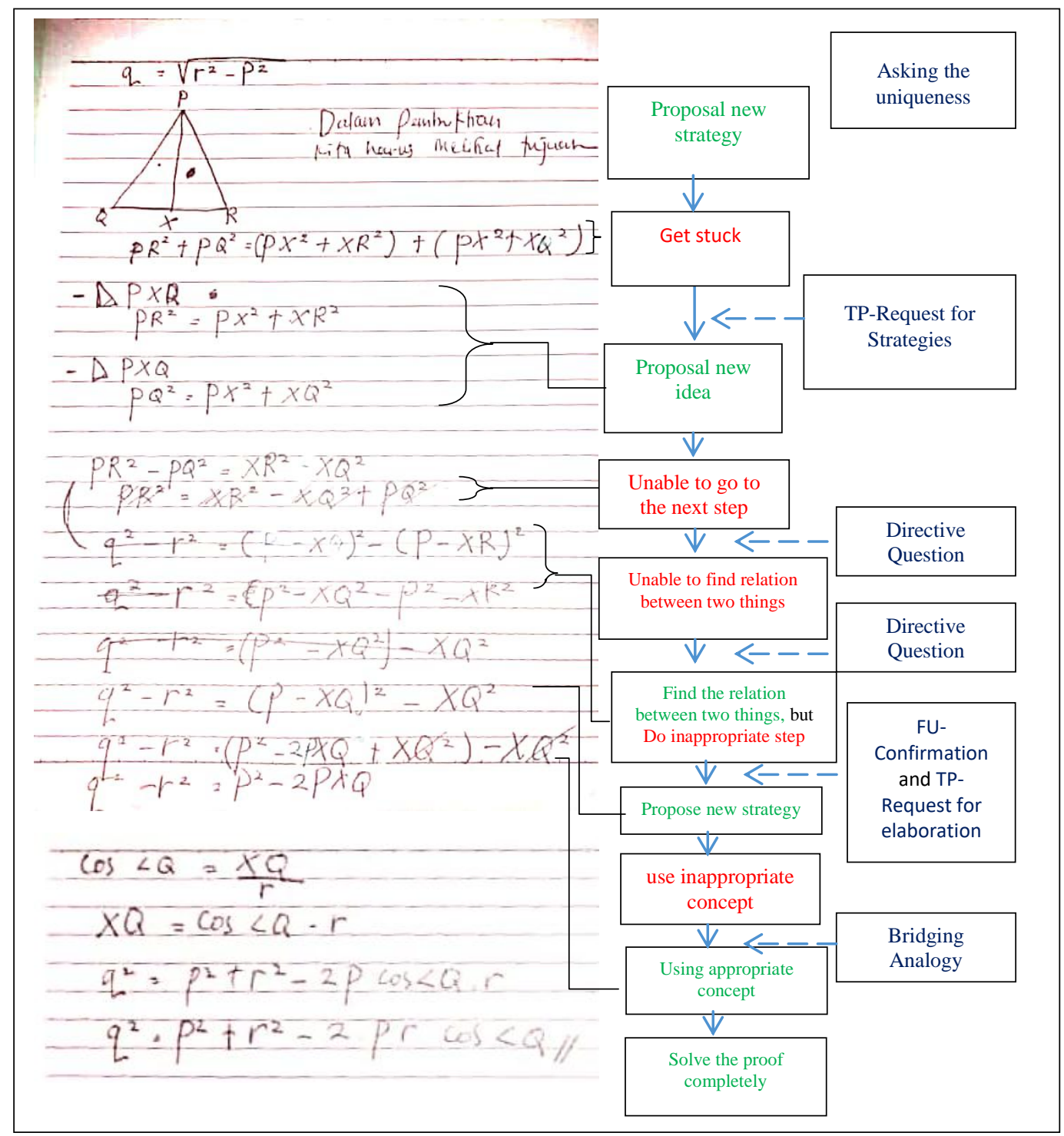

Figure 2. Proving Process Provided by S1 while Scaffolded

The red font is used to indicate difficulties or problems that S1 face in constructing proof, the blue font indicates scaffolding given to help S1 to face the difficulties, and the green font indicates the success of scaffolding given. This research only consist one subject to make the discussions of scaffolding given becomes deeper and focus. From the data, it can be seen that some problems that 
student face in constructing proof are unable to begin proving or unable to devise strategy, getting stuck in the process, unable to go to the next step, unable to find relation between two things or two concepts, doing inappropriate step, and using inappropriate concept. Note that, Difficulty stated in this article means problem that student face, because in some problems student does not think that it is difficulty such as when she uses inappropriate concept.

Difficulties in devising strategy, as Stavrou (2014) found that most of students are still lack of knowing how to start a proof, can be scaffolded by asking what is the characteristics of what to be proven, and ask the students to recall their knowledge that may be used. When subjects get stuck in their process, they can be scaffolded by giving them trans active prompt with requesting for strategies, and if this scaffolding is success they will propose new idea or new strategy. Directive question can be used to scaffold students that unable to go to the next step and unable to find relation between two things. Facilitative utterance and transactive prompt can be used to scaffold student when he/she do inappropriate step, and using inappropriate concept can be scaffolded by bridging analogy. Using inappropriate concept in this article means misconception, that can be scaffolded by using analogy (Dilber \& Duzgun, 2008).

Difficulties in constructing proof, scaffolding given, and development of student's ZPD are summarized in Table 2.

Table 2. Difficulty, Scaffolding, and Development of Student's ZPD

\begin{tabular}{lll}
\hline \multicolumn{1}{c}{ Difficulty } & \multicolumn{1}{c}{ Scaffolding } & \multicolumn{1}{c}{$\begin{array}{c}\text { Development of } \\
\text { Student's ZPD }\end{array}$} \\
\hline $\begin{array}{l}\text { Devising strategy } \\
\text { Getting stuck }\end{array}$ & $\begin{array}{l}\text { Asking uniqueness } \\
\text { Trans active } \\
\text { prompt- Request for } \\
\text { strategies }\end{array}$ & $\begin{array}{l}\text { Propose new strategy } \\
\text { Propose new idea }\end{array}$ \\
Unable to go to the & Directive question & - \\
next step & & \\
Unable to find & Directive question & Find relation \\
relation & & \\
Do inappropriate step & Facilitative utterance - Propose new strategy \\
& & \\
\hline 152 & &
\end{tabular}




\begin{tabular}{llll}
\hline Difficulty & \multicolumn{1}{c}{ Scaffolding } & \multicolumn{1}{c}{$\begin{array}{c}\text { Development of } \\
\text { Student's ZPD }\end{array}$} \\
\hline & confirmation & \\
& Trans active prompt & & \\
& request for elaboration & & \\
& Bridging analogy & Using & appropriate \\
Use inappropriate & & concept & \\
concept & & &
\end{tabular}

\section{CONCLUSION}

Some problems that student face in constructing proof are unable to begin proving or unable to devise strategy, getting stuck in the process, unable to go to the next step, unable to find relation between two things or two concepts, doing inappropriate step, and using inappropriate concept. Difficulties in devising strategy can be scaffolded by asking what is the characteristics of what to be proven, and ask the students to recall their knowledge that may be used. When students get stuck in their process, they can be scaffolded by giving them directive question, and if this scaffolding is success they propose new idea or new strategy. Directive question can be used to scaffold students that unable to go to the next step and unable to find relation between two things. Facilitative utterance and transactive prompt can be used to scaffold student that do inappropriate step, and using inappropriate concept can be scaffolded by bridging analogy. For the next research related to scaffolding with questions, it is needed to compare scaffolding process between male and female students because they might have different sensitivity with question, and what kind of scaffolding that enhance more for male and female.

\section{REFFERENCE}

Anghileri, J. (2006). Scaffolding practices that enhance mathematics. Journal of Mathematics Teacher Education, 9(1), 33-52. https://doi.org/10.1007/s10857-006-9005-9

Baxter, J. A., \& Williams, S. (2010). Mathematics: managing the dilemma of telling. Journal of Mathematics Teacher Education, 13(1), 7-26. https://doi.org/10.1007/s10857-009-9121-4

Belland, B. R., \& Evidence, E. (2017). Instructional scaffolding in STEM education. New York: Springer. Retrieved from 
https://www.oapen.org/download?type=document\&docid=1001944

Bikmaz, F. H., Çelebi, Ö., Ata, A., Özer, E., Soyak, Ö., \& Reçber, H. (2010). Scaffolding strategies applied by student teachers to teach mathematics. Educational Research Association The International Journal of Research in Teacher Education The International Journal of Research in Teacher Education, 1(3), 25-36.

Blanton, M., Sylianou, D., \& David, M. (2009). Understanding instructional scaffolding in classroom discourse on proof. In D. A. Stylianou, M. L. Blanton, \& E. J. Knuth (Eds.), Teaching and learning and learning proof across the Grades: a k-16 perspective (pp. 290-306). Madison Ave.

Cyr, S. (2011). Development of beginning skills in proving and proof writing by elementary school students. Proceedings of the Seventh Congress of the European Society for Research in Mathematics Education, 1-10. http://lettredelapreuve.org/pdf/CERME7/Cerme7_WG1_Cyr.pdf

Dilber, R., \& Duzgun, B. (2008). Effectiveness of analogy on students' success and elimination of misconceptions. Latin-American Journal of Physics Education, $2(3)$,

174-183. https://dialnet.unirioja.es/descarga/articulo/2734605.pdf

Doruk, M. (2019). Preservice mathematics teachers' determination skills of proof techniques: the case of integers. International Journal of Education in Mathematics Science and Technology, 7(4), 335-348. https://www.ijemst.net/index.php/ijemst/article/view/729

Güler, G. (2016). The difficulties experienced in teaching proof to prospective mathematics teachers: academician views. Higher Education Studies, 6(1), 145-158. https://doi.org/10.5539/hes.v6n1p145

Hanna, G. (2000). Proof, explanation and exploration: an overview. Educational Studies in Mathematic, 44(1-2), 5-23. https://doi.org/10.1023/A:1012737223465

Hemmi, K., \& Löfwall, C. (2010). Why do we need proof. CERME 6, Congress of the European Society for Research in Mathematics Education, 201-210. http://www.divaportal.org/smash/record.jsf?pid=diva2:400484

Pantaleon, K. V., Juniati, D., Lukito, A., \& Mandur, K. (2018). The written mathematical communication profile of prospective math teacher in mathematical proving The written mathematical communication profile of prospective math teacher in mathematical proving. Journal of Physics: Conference Series, 947(1), 012070. https://doi.org/10.1088/17426596/947/1/012070

Pfister, M., Moser, E. O., \& Christine, P. (2015). Scaffolding for mathematics teaching in inclusive primary classrooms: a video study. ZDM, 47(7), 1079-1092. https://doi.org/10.1007/s11858-015-0713-4

Podolefsky, N. S. (2008). Analogical scaffolding: by [University of Colorado]. https://pdfs.semanticscholar.org/19bd/ba9831a44b3933cb9e65052c2434af 566889.pdf

Schroeder, C. (2012). Scaffolded assignments: designing structure and support. University of Wisconsin.

Shahrill, M. (2013). Review of effective teacher questioning in mathematics classrooms. International Journal of Humanities and Social Science, $3(17)$, 
https://pdfs.semanticscholar.org/37c9/76100b72367ad137ece1813bb54b3b 2 a568b.pdf

Slavin, R. E. (2006). Educational psychology theory and practice (8th ed.). Pearson.

Stavrou, S. (2014). Common errors and misconceptions in mathematical proving by education undergraduates. Issues in the Undergraduate Mathematics Preparation of School Teachers, 1(March), 1-8. https://eric.ed.gov/?id=EJ1043043

Warli, Cintamulya, I., \& Rahayu, P. (2020). Scaffolding process based on students diagnostic difficulties in proving group problems by using mathematics mapping Scaffolding process based on students diagnostic difficulties in proving group problems by using mathematics mapping. Journal of Physics: $\quad$ Conference $\quad$ Series, 1422(1), 012012. https://doi.org/10.1088/1742-6596/1422/1/012012

Weber, K. (2001). Student difficulty in constructing proofs: the need for strategic knowledge. Educational Studies in Mathematics, 48(1), 101-119. https://doi.org/10.1023/A:1015535614355 